\title{
Sustainable Aquaponics System and its Challenges: A Review
}

\author{
Rashmi Prabha Mishra ${ }^{1 *}$, Sudhir Kumar Das ${ }^{2}$, Navin Kumar ${ }^{3}$ and Jyoti prabha Mishra ${ }^{4}$ \\ ${ }^{1}$ Krishi Vigyan Kendra, Angul, Odisha, India \\ ${ }^{2}$ Dept. of Fisheries Resource Management, WBUAFS, Kolkata, India \\ ${ }^{3}$ District agriculture office, Samastipur, India \\ ${ }^{4} K V K$, Sambalpur, Odisha, India \\ *Corresponding author
}

\section{A B S T R A C T}

Aquaponics (AP) is defined as the combination of hydroponics and recirculating aquaculture system \& is also played a major role in minimizing the negative environmental impacts resulted from intensive fish farming and crop production. It is totally an environmental-friendly production system due to its full recycling potentiality of waste and nutrients. It is a symbiotic integration of two type of food production disciplines

\section{Keywords}

Sustainable, Aquaponics, Challenges

\section{Article Info}

Accepted:

05April 2020

Available Online:

10 May 2020 within a closed recirculating system i.e. (i) aquaculture (the practice of fish farming); and (ii) hydroponics, the cultivation of plants in water without soil. Depending on the specific conditions, aquaponics can provide a sustainable food source in low and medium income countries, especially where climate conditions are favorable. Aquaponics has beneficial reductions for some environmental impacts associated with food production. Besides this it is one of the complex system though it deals with three different concepts of fish, plant and microorganism as a whole. So the water quality management aspects are taken into consideration on priority basis particularly the $\mathrm{pH}$, Nutrient \& phosphorous content of water during this type of culture practice. Otherwise the variations of these parameters may lead to mass killing of fish, plant and beneficial microbes together. Moreover certain key economic points must be given due attention to make Aquaponics system sustainable \& profitable i.e the overall investment cost, Annual operational cost \& Realistic estimates of market prices etc. Considering the food production \& population consumption pattern of our country, It is needed to develop the innovative aquaculture techniques in a sustainable manner. In this context, the aquaponics system played a major role towards environmental, social and financial sustainability which leads to overall sustainability.

\section{Introduction}

Aquaponics (AP) is defined as the combination of hydroponics and recirculating aquaculture system (Rakocy et al., 2003) and is also played a major role in minimizing the negative environmental impacts resulted from intensive fish farming and crop production. It has received great attention due to its ability to maintain water quality, reduce fresh water consumption, and provide a marketable vegetable crop (McMurtry et al., 1997a, 1997b; Adler et al., 2000a; Lennard and Leonard, 2005; Graber and Junge, 2009; 
Danaher et al., 2011, 2013; Pantanella et al., 2011, 2015; Espinosa Moya et al., 2016; Shete et al., 2016). In this type of integration, nutrients excreted by the fish through microbial activity (Elumalai et al., 2017., Munguia-Fragozo et al., 2015; Zou et al., 2016a) are absorbed by hydroponically cultured plants and treating the water before it is recycled to the fish tank (Endut et al., 2009; Tyson et al., 2011; Nichols and Savidov, 2012; Medina et al., 2016; Nuwansi et al., 2016). It is totally an environmental-friendly production system due to its full recycling potentiality of waste and nutrients. In an Aquaponics system, the water quality needed for fish production is maintained through biofilter and/or hydroponic section where: i) plants absorb dissolved fish wastes and products of microbial activity (McMurtry et al., 1993; Danaher et al., 2013; Silva et al., 2015; Goddek et al., 2016; Andriani et al., 2017); ii) several substances are eliminated through gas volatilisation $(\mathrm{CO} 2, \mathrm{CH} 4, \mathrm{~N} 2$, $\mathrm{N} 2 \mathrm{O}, \mathrm{NH} 3$, etc.) by the same processes as in conoestructed wetlands (Mander et al., 2014; Maucieri et al., 2017). Moreover it is regarded as an atypical and complex food production technology on the basis of its integrative character and multiple method of application (Konig et al., 2016). Francis et al., (2003) concluded that the inefficiencies of Aquaponics production can be minimized by proper designing systems and nutrient cycles. As reviewed in Goddek et al., (2015), It can also be considered as a sustainable agricultural production system and, in this respect, Lehman et al., (1993) define sustainable agriculture as "agricultural practices which do not undermine our future capacity to engage in agriculture". There is global concern about how future generations will produce more food in a sustainable manner. Many serious issues found in agriculture sector i.e. it has significant environmental impact on natural resources: Use of high dose of chemicals, the conversion of natural land to agriculture, leaching of nutrients etc. Day by day the use of Nitrogen as chemical fertilizer has exceeded by 20 times the nitrogen content in the oceans 4 and cause severe eutrophication to water bodies 5 . Closing the loop between crops and animals is therefore found as one of the best way to minimize the waste as well as improve water and nutrient efficiency. In the above context, this review paper is aimed to ascertain the potentials, scope of Aquaponics, types, challenges and the sustainability of aquaponics system.

\section{Concept of sustainable Aquaponics system}

Aquaponics is a symbiotic integration of two type of food production disciplines within a closed recirculating system (Thorarinsdottir, 2015) i.e. (i) aquaculture (the practice of fish farming); and (ii) hydroponics, the cultivation of plants in water without soil (Fig. 4).. An aquaponics system filters the nutrient-rich effluent through an inert substrate containing plants. Bacteria metabolize the fish waste, and plants assimilate the resulting nutrients, with the purified water then returning to the fish tanks (Fig. 5). The hydroponic beds function as a biofilter - stripping off ammonia, nitrates, nitrites through nitrogen cycling and making them available for plant uptake (Fig. 6). The system results in a synergistic effect between fish, microorganisms and plants, and encourages sustainable use of water and nutrients, including their recycling capacity. This integration substantially minimizes the cost of input of nutrients and the need for output of waste, unlike when run as seperate systems (Goddek et al., 2015).

\section{Scope and types of Aquaponic system}

Aquaponics has potentiality to improve the livelihoods of households and communities. Fish is an important source of protein in lowland medium income countries and 
vegetables improve nutrition (Tacon and Metian, 2013).

Aquaponics can increase food security and the food sovereignty. However technical skill and knowledge is needed to start commercially intensive aquaponics system. Under favorable climatic conditions (tropics and subtropics), aquaponic systems may be very simple, consisting of uninsulated outdoor units. Little and Bunting (2015) state that very few inputs are needed for a basic unit. Depending on the specific conditions, aquaponics can provide a sustainable food source in low and medium income countries, especially where climate conditions are favorable. Aquaponics has beneficial reductions for some environmental impacts associated with food production. Generally, there are three type of aquaponics system:

\section{Characteristics of sustainable Aquaponics}

The sustainability in Aquaponics can be characterized by the following seven ways

\section{Helps in water saving}

Water quality and water availability are two limiting factors for growing food around the world. Aquaponics needs less water by recirculating it through the fish and plant system. One hundred gallons of water added to an aquaponic system, could be recycled for several days, maybe a week or more. But that same amount of water in case of conventional method of soil garden preparation would be lost by vaporization, leaching or in other ways. (Bernstein, 2011).

\section{Minimize the cost and efforts during Soil management}

Aquaponics decreases the cost and efforts for soil management, and that often throws off traditional gardeners. In case of aquaponics it provides the plant everything of its requirement, nutrients, oxygen and water in perfect combination and totally sustainable.

\section{Growing in any favourable weather conditions}

Aquaponics allows food to be produced in many places that would not otherwise be able to grow. But these aqauponics can also be setup inside greenhouse, warehouse or outdoors depending upon favorable weather conditions.

\section{Act as natural fertilizer}

Aquaponics gets its nutrients from the water source and the byproducts of the fish system, and possibly from the media materials as well. In traditional agriculture often used mined or manufactured chemical and synthetic fertilizers, pesticides and herbicides. These are natural resource intensive to produce, cause significant pollution in the process and don't provide a sustainable model. Since aquaponics creates a natural ecosystem, it is capable enough to supply nutrients that plants need without chemicals. This is helpful to produce good quality of food. It also eliminates labor and time costs for machinery and human resources commonly used to apply chemical fertilizers, herbicides and pesticides are no longer necessary.

\section{Produce no waste}

Since aquaponics create a natural ecofriendly system there is no formation of waste materials here. Any solids collected from the fish system can be added to compost which can act as organic manure for the plants. Any unharvested plant material from the system can also be composted or can be fed to the animals. 


\section{Reduce "food miles"}

Long distance transportation of food makes huge cost for food consumer. Aquaponics allows to produce food in home which ensures nutritional quality though it is fresh and having less stress during long distance transportation.

\section{Financial sustainability}

Aquaponics can be used to improve the livelihoods of households and communities (Konig et al., 2016). It increases economic efficiency because several key costs, such as nutrients, land and water are substantially reduced and component operating, and infrastructural costs are shared (Bildaru et al., 2011). It can be economically profitable within a very less amount of time by following some of the essential criteria like growing the right products, having the right market place, selling at the right price and maintaining costs under control. Thus, financial sustainability is maintained by aquaponics.

\section{Major challenges of aquaponics system technical challenges}

\section{Maintenance of $\mathrm{pH}$ of water}

The aquaponics is one of the complex system though it deals with three different concepts of fish, plant and microorganism as a whole. So the water quality management aspects are taken into consideration on priority basis particularly the $\mathrm{pH}$ content of water during this type of culture practice. Otherwise the variations of $\mathrm{pH}$ may lead to mass killing of fish, plant and beneficial microbes together.

In general, the $\mathrm{pH}$ requirement for most of the plant species is varied from 6 to 6.5 to enhance the nutrient uptake (Goddek et al., 2015). Fish, in contrast, need a pH range of 7 -
9 to show the best growth performance (Boyd 1998). The nitrifying bacteria requires a high $\mathrm{pH}$ level (>7).

In general, three types of bacteria are playing the critical role in this nitrification process and their optimal $\mathrm{pH}$ levels are ranged from 7.5 (Keen and Prosser 1987), 7.0-7.5 (Hatayama et al., 2000) and 8.0-8.3 (Blackburne et al., 2007) for Nitrobacter, Nitrosomonas and Nitrospira, respectively. Therefore, the ideal $\mathrm{pH}$ range applicable for this whole aquaponics system is 6.0-8.0. Maintaining this $\mathrm{pH}$ range is quite critical in stabilizing the water quality parameters in this aquaponics system.

\section{Maintenance of nutrient content of water}

Nutrient balance is another important aspect, which is derived mostly from the fish feed after the end of nitrification process. This feed can be divided into assimilated feed, uneaten feed and soluble fish excreta (Montanhini Neto and Ostrensky, 2015). Soluble excreta are mainly the ammonia and are the most available mineral until it is degraded into nitrite and nitrate by nitrifying bacteria (Lekang and Kleppe, 2000; Chen et al., 2006). Here the uneaten feed and solid faces need to be solubilized from organic material to ionic mineral forms that are easily assimilated by plants. The solubilization rate usually varies among minerals and do not accumulate equally (Seawright et al., 1998; Rakocy and Hargreaves 1993), which influences their concentration in the water. Review study for current practices in RAS suggested that the solid wastes could be partially solubilized if they were mechanically filtered out on a daily basis (Cripps and Bergheim 2000). These filtered wastes can be mineralized externally and reinserted into the hydroponic beds (Goddek et al., 2015). Review study also showed that the physical and chemical mechanisms of solubilization of 
all involved microorganisms were not yet fully realized and understood (van Rijn 2013). Hence, more research is needed on fish waste solubilization with the objective to transform all added nutrients into plant biomass.

\section{Maintenance of phosphorus content of water}

Maintaining the phosphorus balance is also critical as this macro-nutrient is essential for both vegetative and flowering stages of plant growth.

\section{Pest and disease management}

Among other technical challenges, pest and disease management need special attention as the conventional pesticides cannot be used in aquaponics system as it may create toxicity for the fish and other desired biofilm production (e.g., autotrophic nitrifying biofilm).

Table. 1 Types of aquaponics system

\begin{tabular}{|c|c|c|}
\hline Type & Usage & Reference \\
\hline $\begin{array}{l}\text { Home-based } \\
\text { aquaponics (HA) }\end{array}$ & $\begin{array}{l}\text { - Food products for local consumption purpose is produced } \\
\text { from Home-based aquaponics. } \\
\text { - It is mostly preferable for hotels, prisons, supermarkets, } \\
\text { and shopping malls as ideal settings. } \\
\text { - HA is also decreasing the risk of obesity and unhealthy } \\
\text { diets due to both the quantity and the quality of protein, } \\
\text { fruit and vegetable uptake by home activities }\end{array}$ & (Somerville et al., 2014). \\
\hline $\begin{array}{l}\text { Factory-based } \\
\text { aquaponics (FA) }\end{array}$ & $\begin{array}{l}\text { - Factory-based aquaponics (FA) is an industrial food } \\
\text { production system that is intended for international trade } \\
\text { and subject to the regulations of the receiving market. } \\
\text { - Either fresh water aquaponics or seawater aquaponics can } \\
\text { be developed as this model. Seawater aquaponics may } \\
\text { exhibit more economic benefits for seafood production and } \\
\text { the low-salinity or high-salinity marine plants are used } \\
\text { This model of aquaponics can reduce operational costs by } \\
\text { increasing fish productivity and harvest of vegetables. }\end{array}$ & $\begin{array}{l}\text { (Thorarinsdottir,2015) } \\
\text { and (Waller et al., 2015). } \\
\text {. }\end{array}$ \\
\hline $\begin{array}{l}\text { Building-based } \\
\text { aquaponics (BA) }\end{array}$ & $\begin{array}{l}\text { - Building-based aquaponics (BA) is a medium-scale } \\
\text { infrastructure. The idea behind building-based aquaponics } \\
\text { is from the innovative forms of green architecture that aim } \\
\text { to combine food, architecture, production and design to } \\
\text { produce food on buildings in urban areas }\end{array}$ & (Specht et al., 2014). \\
\hline
\end{tabular}


Table.2 Types of aquaponics system based on media based growing: Aquaponics

\begin{tabular}{|c|c|c|}
\hline Туре & Method used & Usage \\
\hline $\begin{array}{l}\text { Deep water culture } \\
\text { (DWC) systems }\end{array}$ & $\begin{array}{l}\text { DWC involves plants in Styrofoam sheets } \\
\text { that float over grow beds with air supplied. }\end{array}$ & $\begin{array}{l}\text { DWC is the most simple system for large } \\
\text { commercial aquaponics growing plants like } \\
\text { lettuce, basil, and other leafy plants. }\end{array}$ \\
\hline $\begin{array}{l}\text { Media-filled bed } \\
\text { systems (Flood and } \\
\text { Drain Systems) }\end{array}$ & $\begin{array}{l}\text { The media is used in grow beds to support } \\
\text { the roots of the plants and for filtration. }\end{array}$ & $\begin{array}{l}\text { These are the most popular design for small- } \\
\text { scale aquaponics as they are efficient with } \\
\text { space, relatively low cost, and suitable for } \\
\text { beginners as they are a very simple in design. }\end{array}$ \\
\hline $\begin{array}{l}\text { Nutrient film } \\
\text { technique (NFT) }\end{array}$ & $\begin{array}{l}\text { NFT uses of plastic pipes laid out } \\
\text { horizontally to grow vegetables. Water is } \\
\text { lifted from the biofilter into each hydroponic } \\
\text { pipe with a small amount of flow creating a } \\
\text { shallow stream of nutrient-rich water flowing } \\
\text { along the bottom. The pipe contains a } \\
\text { number of holes along the top where plants } \\
\text { are placed into to grow. }\end{array}$ & $\begin{array}{l}\text { NFT aquaponics shows potential for custom } \\
\text { aquaponics designs. While it uses less water } \\
\text { than the other two methods. But it is } \\
\text { expensive and complicated. }\end{array}$ \\
\hline
\end{tabular}

Source: El-Essawy (2018)

Table. 3 Types of aquaponics system based on farming scale

\begin{tabular}{|c|c|c|}
\hline Type & Usage & Reference \\
\hline Small-scale Aquaponics & $\begin{array}{l}\text { One of the best practices for producing organic food } \\
\text { and vegetables as it is a small-scale aquaponics } \\
\text { system. It is a sustainable technology that requires } \\
\text { minimal water and space A small unit is used here } \\
\text { and placed and integrated into the interior design of } \\
\text { homes, offices, kitchens, and workspaces. }\end{array}$ & $\begin{array}{l}\text { (Menon } \\
\text { al.,2013) }\end{array}$ \\
\hline Low-tech Aquaponics & $\begin{array}{l}\text { Aquarium can be transformed easily into an exclusive } \\
\text { herb production unit. It demands very low cost and } \\
\text { the process requires no special crafts, skills, or tools. } \\
\text { It is a fantastic way for the people living in urban to } \\
\text { get closer to nature and grow their own fresh herbs, } \\
\text { leafy vegetables, and fresh fish protein with less } \\
\text { production costs }\end{array}$ & $\begin{array}{l}\text { (Nicolae et al., } \\
\text { 2015). }\end{array}$ \\
\hline Micro Aquaponics & $\begin{array}{l}\text { An innovative and smart design concept for a micro- } \\
\text { scaled aquaponics system paves the way for a new } \\
\text { concept of eco-farming systems. The main aim of this } \\
\text { system is to use the value of the residue in the water } \\
\text { and convert it through a combination of } \\
\text { multidisciplinary efforts and thus low environmental } \\
\text { impact technologies to become valuable products. }\end{array}$ & $\begin{array}{l}\text { (Khakyzadeh et } \\
\text { al., 2015) and } \\
\text { (Guerrero et al., } \\
\text { 2013). }\end{array}$ \\
\hline
\end{tabular}




\section{Impacts of Aquaponics system}

Table.4 Environmental, economic and social impacts of aquaponics

\section{Environmental impacts}

(1) Use and recycling of water resources

(2) Energy consumption and production

(3) Recycling of organic waste

(4) New landscape opportunities

\section{Economic impacts}

(1) Food production increased

(2) utilization unemployed labor

(3) Using the waste stream to meet the total energy needs of an aquaponics system.

\section{Social Impacts}

(1) Improving community food security

(2) Providing a source of relatively cheap of protein

(3) Important to low-income individuals in both developing and developed countries.

\section{Sources: Anonymous (2016)}

Table.5 Fish and Plant species used in Aquaponics system

\begin{tabular}{|c|c|}
\hline $\begin{array}{l}\text { Fish Species (Source : (Knaus et } \\
\text { al.,2017). }\end{array}$ & Plant Species (Source : (Aguilara et al.,2014). \\
\hline $\begin{array}{l}\text { Common carp, Tilapia, Silver } \\
\text { carp, Grass carp, Barramundi, } \\
\text { Jade perch, Catfish, Trout, } \\
\text { Salmon, Murray cod and } \\
\text { Largemouth bass }\end{array}$ & $\begin{array}{l}\text { Okra, Tatsoi, Kale, Mint, Thyme, Dill, Scallions, Chives, Cilantro, Taro, } \\
\text { Watercress, Salad rocket, Edible flowers, small fruit trees, Root } \\
\text { vegetables such as Onion, Carrot, Beets, Radish and Taro etc. }\end{array}$ \\
\hline
\end{tabular}

Figure.1 Symbiotic relationship in sustainable aquaponics system

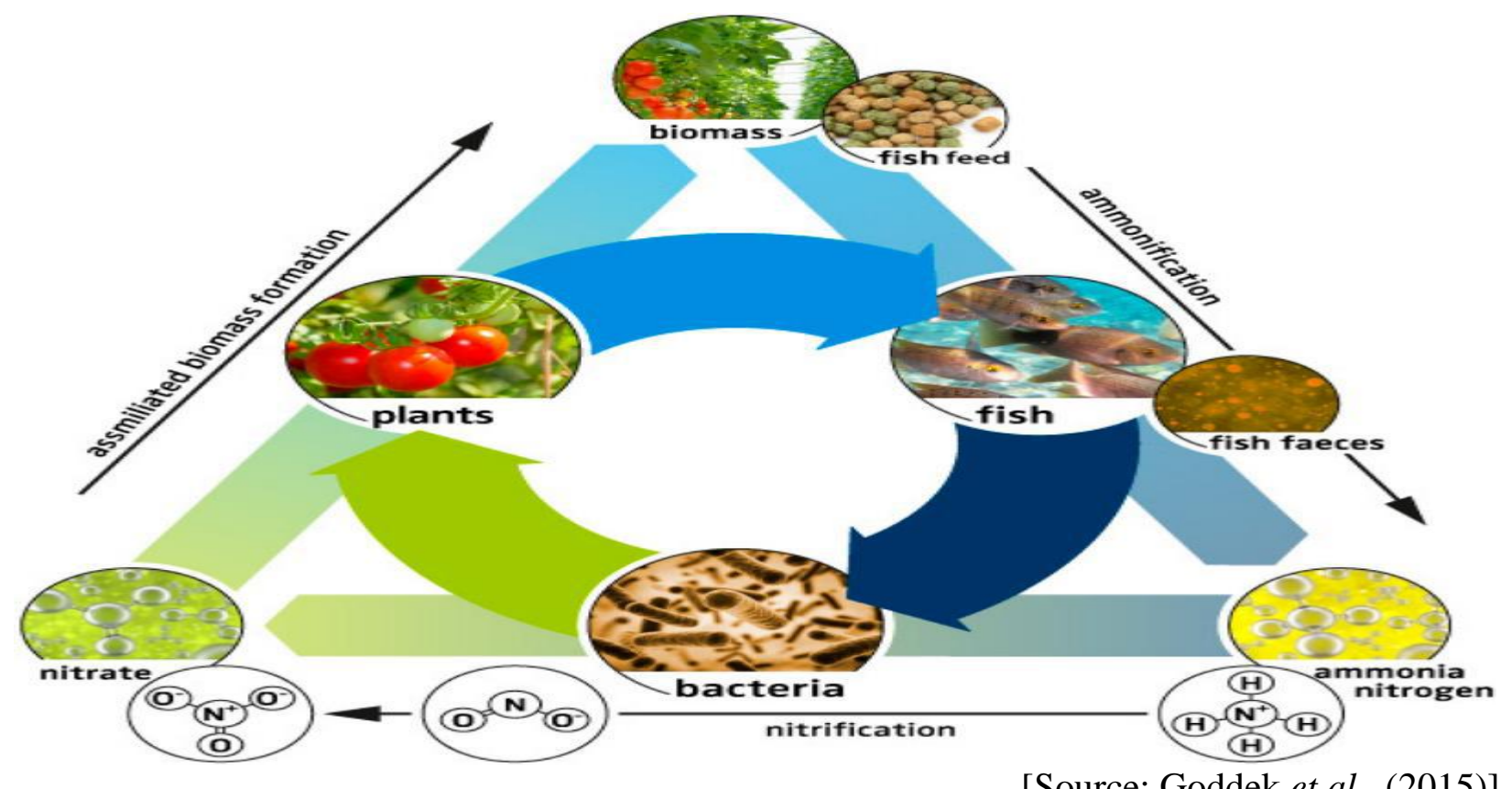

[Source: Goddek et al., (2015)] 
Fig.2 Water cycle in sustainable aquaponics system

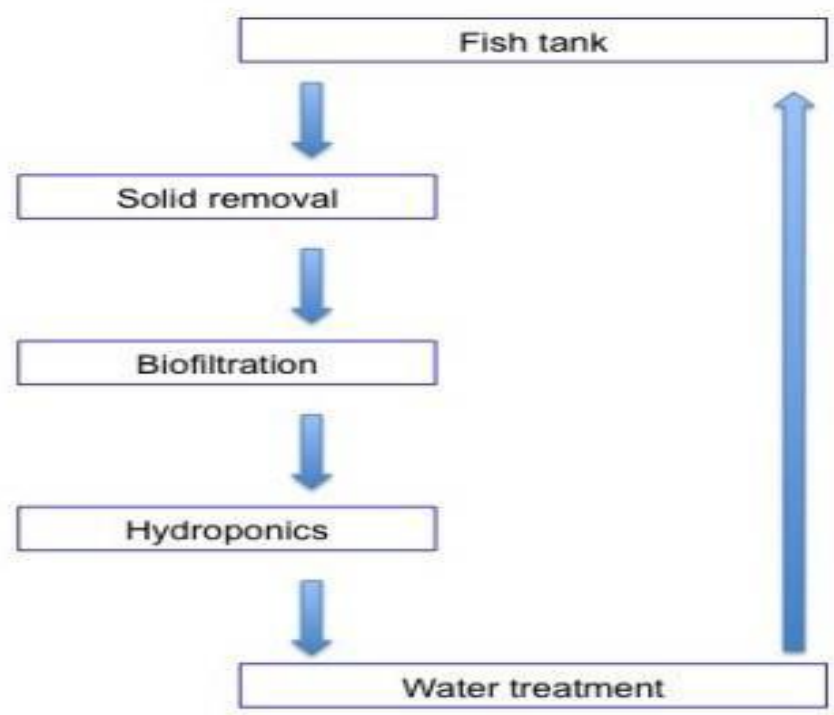

Source: Lia et al., (2018)

Fig.3 Nitrogen cycle in sustainable aquaponics system

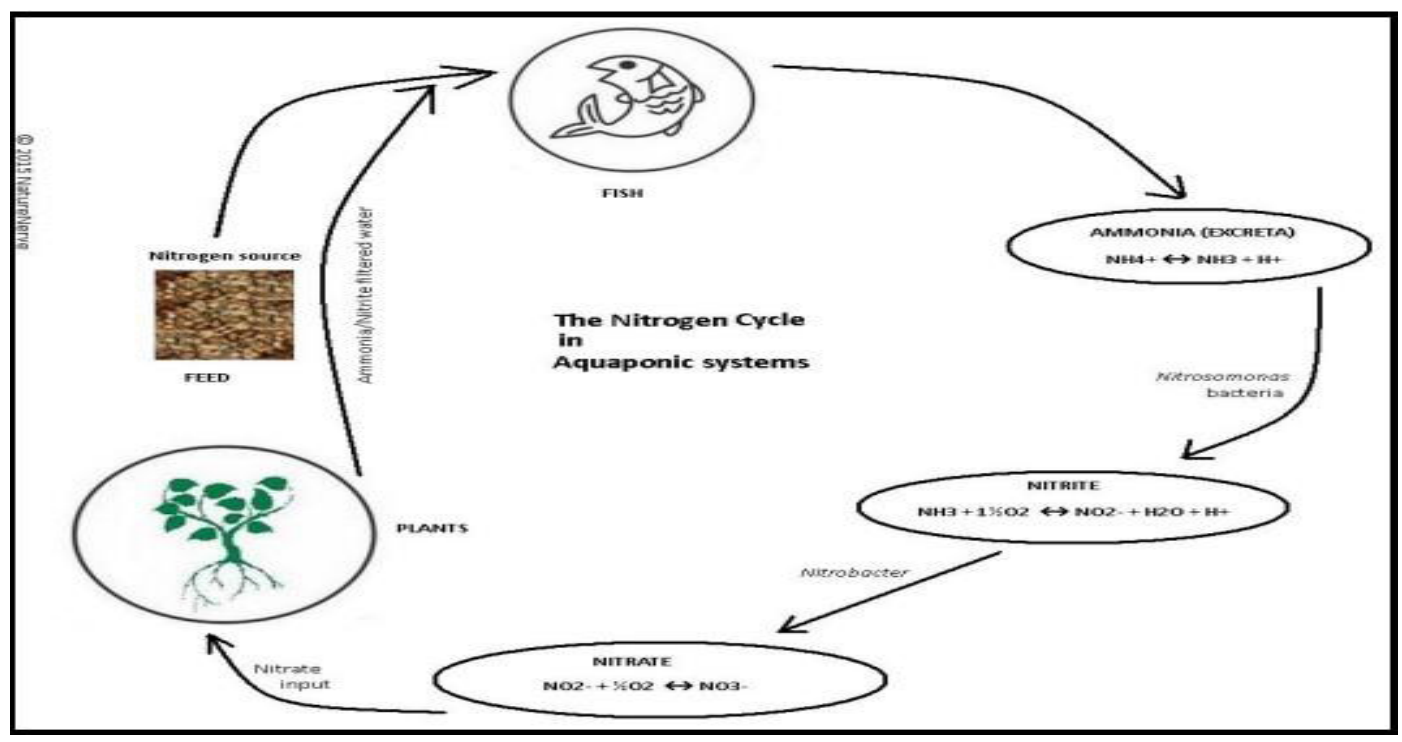

Source: Asish (2017)

\section{Use of antibiotics and fungicides}

It is needed for control of fish diseases but are not suggested as it may be lethal for the plant growth, nitrifying biofilm and other nutrient solubilizing microorganisms.

All of the above constraints demand innovative research for unique pest and disease management solution that minimize the harmful impacts on the fish, plants, and microorganisms.

\section{Economic challenges}

Certain key economic points must be given due attention to make Aquaponics system 
profitable. These includes :-

1) The overall investment cost

2) Annual operational cost

3) Realistic estimates of market prices

Basically, the cost of fish production in an indoor system is two to three times higher than growing fish at the outdoor/ponds (Engle 2015). Hence, suitable market development for this kind of indoor products (i.e., produced at aquaponics system) is important, where the consumers' willingness to pay will be a little higher than the average market/market price. Besides these, the production cost is usually higher for producing fish in recirculating aquaculture unit compared to producing vegetables from the hydroponic unit that may lead to incur a net profit loss for the aquaponics system.

Conclusion of the study is as follows:

Considering the food production and population consumption pattern of our country, It is needed to develop the innovative aquaculture techniques in a sustainable manner. To address this promising issue and improve the potential to supply fresh food, advanced technologically and integrated systems required to be explored to ensure a continuous food supply. In this context Aquaponics exhibits the prospect for the sustainable development of food production. Besides it saves water, eliminate soil problem and other challenges faced in traditional cultivation. Thus, the aquaponics system played a major role towards environmental, social and financial sustainability which leads to overall sustainability.

\section{References}

Adler PR, Harper JK, Wade EM, Takeda F, Summerfelt ST, (2000a): Economic analysis of an aquaponic system for the integrated production of rainbow trout and plants. Int. J. Recirc. Aquacult. 1:1534.

Aguilara-Titus, J., Cao, Y., Kazyak, E., Kumar, K., Li, K., Louie, A., and Misner, K. (2014): Evaluating Alternative Nutrient Sources in Subsistence-Level Aquaponic Systems (Doctoral dissertation).

Andriani Y, Dhahiyat Y, Zahidah IZ, (2017): The effect of stocking density ratio of fish on water plant productivity in Aquaponics culture. Nus. Biosci. 9:31-5.

Bernstein, S. (2011): Aquaponic gardening: a step-by-step guide to raising vegetables and fish together. New society publishers.

Blackburne, R., Vadivelu, V. M., Yuan, Z., and Keller, J. (2007): Kinetic characterisation of an enriched Nitrospira culture with comparison to Nitrobacter. Water Research 41(14):3033-3042.

Blidariu, F., and Grozea, A. (2011): Increasing the economical efficiency and sustainability of indoor fish farming by means of aquaponics-review. Scientific Papers Animal Science and Biotechnologies, 44(2), 1-8.

Boyd, C. E. (1998). Water quality for pond aquaculture. International Center Experimental Station

Bunting, S. W., and Little, D. (2015): Urban aquaculture for resilient food systems. Cities and Agriculture: Developing Resilient Urban Food Systems, 312-335.

Chen, S., Ling, J. and Blancheton, J. P. (2006). Nitrification kinetics of biofilm as affected by water quality factors. Aquacultural Engineering 34(3):179-197.

Cripps, S. J., and Bergheim, A. (2000).

Danaher JJ, Shultz RC, Rakocy JE, Bailey DS, (2011): Effect of a parabolic screen filter on water quality and production of Nile tilapia (Oreochromis niloticus) and water spinach (Ipomoea aquatica) in a recirculating raft aquaponic system. Int. J. Recirc. Aquac. 12:35-53.

Danaher JJ, Shultz RC, Rakocy JE, Bailey DS, (2013): Alternative solids removal for warm water recirculating raft aquaponic systems. J. World Aquacult. Soc. 44:37483. 
Endut A, Jusoh A, Ali N, Wan Nik WNS, Hassan A, (2009): Effect of flow rate on water quality parameters and plant growth of water spinach (Ipomoea aquatica) in an aquaponic recirculating system. Desalin. Water Treat. 5:19-28.

Engle, C. R. (2015). Economics of aquaponics. SRAC (Southern Regional Aquaculture Center) Publication No. 5006.

Espinosa Moya EA, Angel Sahagun CA, Mendoza Carrillo JM, Albertos Alpuche PJ, Alvarez-Gonzalez CA, MartinezYanez R, (2016): Herbaceous plants as part of biological filter for aquaponics system. Aquacult. Res. 47:1716-26.

Fragoso, T.M. and Neto, F.L. (2015) Bayesian Model Averaging A Systematic Review and Conceptual Classification. arXiv1509.08864.

Francis C, Lieblein G, Gliessman S, Breland TA, Creamer N, Harwood R, (2003): Agroecology: the ecology of food systems. J. Sustain. Agr. 22:99-118.

Goddek S, Delaide B, Mankasingh U, Ragnarsdottir KV, Jijakli $\mathrm{H}$, Thorarinsdottir R, (2015). Challenges of sustainable and commercial aquaponics. Sustainability 7:4199-24.

Goddek S, Schmautz Z, Scott B, Delaide B, Keesman KJ, Wuertz S, Junge R, (2016). The effect of anaerobic and aerobic fish sludge supernatant on hydroponic lettuce. Agronomy 6:37.

Goddek, S., Delaide, B., Mankasingh, U., Ragnarsdottir, K. V., Jijakli, H., and Thorarinsdottir, R. (2015): Challenges of sustainable and commercial aquaponics. Sustainability, 7(4): 4199-4224.

Graber A, Junge R, (2009). Aquaponic systems: nutrient recycling from fish wastewater by vegetable production. Desalination 246:147-56.

Guerrero, J., Edwards, C. F., Wan, D. Y., and Sheth, V. (2013): Using Wireless Sensor Network Controls to Monitor an Indoor Aquaponics System. RET: Research Experiences for Teachers on Sensor Networks.

Hatayama, R., Takahashi, R., Ohshima, M.,
Shibasaki, R., and Tokuyama, T. (2000). Ribulose-1,5-bisphosphate carboxylase/ oxygenase from an ammonia-oxidizing bacterium, Nitrosomonas spp. K1: Purification and properties. Journal of Bioscience and Bioengineering 90(4):426-430.

Keen, G. A., and Prosser, J. I. (1987). Interrelationship between $\mathrm{pH}$ and surface growth of Nitrobacter. Soil Biology and Biochemistry 19(6):665-672.

Khakyzadeh, V., Luque, R., Zolfigol, M. A., Vahidian, H. R., Salehzadeh, H., Moradi, V., ... and $\mathrm{Xu}, \mathrm{K}$. (2015): Waste to wealth: a sustainable aquaponic system based on residual nitrogen photoconversion. RSC Advances, 5(5), 3917-3921. 23

Knaus, U., and Palm, H. W. (2017): Effects of the fish species choice on vegetables in aquaponics under spring-summer conditions in northern Germany (Mecklenburg Western Pomerania). Aquaculture, 473, 62-73.

Konig B, Junge R, Bittsanszky A, Villarroel M, Komives T, (2016). On the sustainability of aquaponics. Ecocycles 2:26-32.

Konig, B., Junge, R., Bittsanszky, A., Villarroel, M., and Komives, T. (2016): On the sustainability of aquaponics. Ecocycles, 2(1), 26-32.

Lehman H, Clark EA, Weise SF, (1993). Clarifying the definition of sustainable agriculture. J. Agr. Environ. Ethic. 6:12743.

Lekang, O.I., and Kleppe, H. (2000). Efficiency of nitrification in trickling filters using different filter media. Aquacultural Engineering 21(3):181-199.

Lennard WA, Leonard BV, (2005). A comparison of reciprocating flow versus constant flow in an integrated, gravel bed, aquaponic test system. Aquacult. Int. 12:539-53.

Li, C., Lee, C. T., Gao, Y., Hashim, H., Zhang, X., Wu, W. M., and Zhang, Z. (2018): Prospect of Aquaponics for the Sustainable Development of Food Production in Urban. Chemical 
Engineering Transactions, 63: 475-480.

Mander, Ü., Tournebize, J., Kasak, K., Mitsch, W.J., (2014): Climate regulation by free water surface constructed wetlands for wastewater treatment and created riverine wetlands. Ecol. Eng., http://dx.doi.org/10.1016/j.ecoleng.2013.0 5.004 (in press).

Maucieri C, Barbera AC, Vymazal J, Borin M, (2017). A review on the main affecting factors of greenhouse gases emission in constructed wetlands. Agr. Forest Meteorol. 236:175-93.

McMurtry MR, Sanders DC, Cure JD, Hodson RG, (1997a). Effects of biofilter/culture tank volume ratios on productivity of a recirculating fish/vegetable co-culture system. J. Appl. Aquacult. 7:33-51.

McMurtry MR, Sanders DC, Cure JD, Hodson RG, Haning BC, St Amand EC, (1997b). Efficiency of water use of an integrated fish/vegetable co-culture system. J. World Aquacult. Soc. 28:420-8.

McMurtry MR, Sanders DC, Patterson RP, Nash A, (1993). Yield of tomato irrigated with recirculating aquacultural water. J. Prod. Agric. 6:428-32.

Medina M, Jayachandran K, Bhat MG, Deoraj A, (2016). Assessing plant growth, water quality and economic effects from application of a plant-based aquafeed in a recirculating aquaponic system. Aquacult. Int. 24:415-27.

Menon, R., Sahana, G. V., Shruthi, V., and Suganya, R. (2013): Small Scale Aquaponic System. International Journal of Agriculture and Food Science Technology, 4(10), 970-980.

Miličić, V., Thorarinsdottir, R., Santos, M., and Hančič, M. (2017): Commercial aquaponics approaching the european market: To consumers' perceptions of aquaponics products in europe. Water, 9(2): 80 .

Montanhini Neto, R., and Ostrensky, A. (2015). Nutrient load estimation in the waste of Nile tilapia Oreochromis niloticus (L.) reared in cages in tropical climate conditions. Aquaculture Research
46(6):1309-1322.

Nichols MA, Savidov NA, (2012). Aquaponics: a nutrient and water efficient production system. Acta Hortic. 947:129-32.

Nicolae, C. G., Popa, D. C., RAHOVEANU, A., Dumitrache, F., Mocuța, D., and Elia, E. (2015): Low-tech aquaponic system based on an ornamental aquarium. Scientific Papers: Series D, Animal Science-The International Session of Scientific Communications of the Faculty of Animal Science, 58.

Nuwansi KKT, Verma AK, Prakash C, Tiwari VK, Chandrakant MH, Shete AP, Prabhath GPWA, (2016). Effect of water flow rate on polyculture of koi carp (Cyprinus carpio var. koi) and goldfish (Carassius auratus) with water spinach (Ipomoea aquatica) in recirculating aquaponic system. Aquacult. Int. 24:38593.

Pantanella E, Cardarelli M, Danieli PP, MacNiven A, Colla G, (2011). Integrated aquaculture - floating agriculture: is it a valid strategy to raise livelihood?. Acta Hortic. 921:79-86.

Pantanella E, Cardarelli M, Di Mattia E, Colla G, (2015). Aquaponics and food safety: effects of uv sterilization on total coliforms and lettuce production. Acta Hortic. 1062:71-6.

Rakocy J, Masser M, Losordo T, (2012). Recirculating aquaculture tank production systems: aquaponics-integrating fish and plant culture. Southern Regional Aquaculture Center Publication\# 454.

Rakocy J, Shultz RC, Bailey DS, Thoman ES, (2003). Aquaponic production of tilapia and basil: comparing a batch and staggered cropping system. pp. 63-69 in South Pacific Soilless Culture Conference-SPSCC 648. Res. 32:1932-8.

Rakocy, J., and Hargreaves, J. E. (1993). Integration of vegetable hydroponics with fish culture: A review. pages 112-136 in J. K. Wang, editor. Aquacultural Engineering Conference. American Society for Agricultural Engineers, St. Joseph, MI, USA. 
Seawright DE, Stickney RR, Walker RB, (1998). Nutrient dynamics in integrated aquaculture-hydroponics systems. Aquaculture 160:215-37.

Shete AP, Verma AK, Chadha NK, Prakash C, Peter RM, Ahmad I, Nuwansi KKT, (2016). Optimization of hydraulic loading rate in aquaponic system with Common carp (Cyprinus carpio) and Mint (Mentha arvensis). Aquacult. Eng. 72:53-7.

Silva L, Gasca-Leyva E, Escalante E, Fitzsimmons KM, Lozano DV, (2015). Evaluation of biomass yield and water treatment in two aquaponic systems using the dynamic root floating technique (DRF). Sustainability 7:15384-99.

Simon Goddek, Boris Delaide, Utra Mankasingh, Kristin Vala Ragnarsdottir, Haissam Jijakli and Ragnheidur Thorarinsdottir (2015): Challenges of Sustainable and Commercial AquaponicsSustainability 2015, 7, 41994224

Somerville, C., Cohen, M., Pantanella, E., Stankus, A., and Lovatelli, A. (2014): Small-scale aquaponic food production: integrated fish and plant farming. $F A O$ Fisheries and Aquaculture Technical
Paper, (589), I.

Specht, K., Siebert, R., Hartmann, I., Freisinger, U. B., Sawicka, M., Werner, A., ... and Dierich, A. (2014): Urban agriculture of the future: an overview of sustainability aspects of food production in and on buildings. Agriculture and human values, 31(1), 33-51.

Tacon, A. G., and Metian, M. (2013): Fish matters: importance of aquatic foods in human nutrition and global food supply. Reviews in Fisheries Science, 21(1), 2238.

Tyson RV, Treadwell DD, Simonne EH, (2011). Opportunities and challenges to sustainability in aquaponic systems. HortTechnol. 21:6-13.

van Rijn, J. (2013). Waste treatment in recirculating aquaculture systems. Aquacultural Engineering 53:49-56.

Zou Y, Hu Z, Zhang J, Xie H, Liang S, Wang J, Yan R, (2016a). Attempts to improve nitrogen utilization efficiency of aquaponics through nitrifies addition and filler gradation. Environ. Sci. Pollut. R. 23:6671-9.

\section{How to cite this article:}

Rashmi Prabha Mishra, Sudhir Kumar Das, Navin Kumar and Jyoti prabha Mishra. 2020. Sustainable Aquaponics System and its Challenges: A Review. Int.J.Curr.Microbiol.App.Sci. 9(05): 577-588. doi: https://doi.org/10.20546/ijcmas.2020.905.065 